\title{
O ESTILO EM COMO SE DEVE ESCREVER A HISTÓRIA, DE LUCIANO ${ }^{1}$
}

\author{
Eduardo Sinkevisque \\ Universidade Estadual de Campinas/ FAPESP
}

Você vê como esse é um princípio apropriado, na medida para a história e adequado ao tipo de discurso? Mas onde se encontra a utilidade da arte e dos conselhos? Não na criação do que é necessário, mas para seu uso conveniente.

Luciano de Samósata. Hist. conscrib. sit. Trad. Jacyntho Lins Brandão

\begin{abstract}
Although mixed, The way to write history is a document written mostly in middle style. Even though Lucian uses metaphors in the letter to Philo among other tropes and figures, comparison is one of the style resources most present in the text, maybe the main resource used. Not all cases of comparison used in The way to write history were presented, but when discussing some of them it is considered that comparison is a characteristic resource of the style Lucian uses. That is, according to the decorum of a treatise-moral demonstrative-deliberative letter of the vituperative kind. In order to make the text effective, the didactic and vice correcting functions demand imitation ways using a middle/ low style.
\end{abstract}

KEYWORDS: Lucian of Samosata; rhetoric; satire; style; The way to write history.

^ esinkevisque@hotmail.com

${ }^{1}$ Faço as citações do texto de Luciano por meio da tradução de Jacyntho Lins Brandão (cf. Brandão, J. L. Como se deve escrever a história. Edição bilíngue. Trad. e ensaio de Jacyntho Lins Brandão. Belo Horizonte: Tessitura, 2009). Somente tive acesso ao ensaio de Brandão após a escrita deste meu texto. Consultei apenas a tradução de Luciano por meio de uma fotocópia a mim oferecida, gentilmente, por Brandão, a quem agradeço. Neste sentido, a numeração das páginas referidas respeita a "fonte" consultada, podendo não coincidir com a paginação do livro editado. 
s sentidos de adequação e conveniência dos excertos acima, escolhidos como epígrafe, permitem ao leitor inferir que Luciano considera fundamental a questão do decoro, tanto para a escrita da história quanto para a exortação da arte histórica. O primeiro, em chave irônica interrogativa patética, ridiculariza a falta de decoro do proêmio em certa história. Denuncia, por meio da tópica da monstruosidade, a desproporção a ser evitada entre as partes do discurso histórico. $\mathrm{O}$ segundo é um comentário sobre a produção do discurso parenético ou exortativo, o que hoje chamaríamos metalinguagem. Em outras palavras, comentário do texto sobre o próprio texto, espécie de prescrição. Trata, em tom sério, também interrogativo, de advertir que a história e as prescrições sobre história sejam úteis, desde que usadas convenientemente. Abstraídos do texto e lidos no texto, os trechos evidenciam não apenas o conhecimento que Luciano tem sobre decoro, mas a mistura do sério com o jocoso, a partir da qual o polígrafo de Samósata compóe o Como se deve escrever a história. Escolhi esses extratos, entre muitos, por julgálos emblemáticos da empreitada a que me proponho. Ou seja, interpretar a comparação (o uso do como, prótase de similitude), típica do estilo médio, como recurso próprio do gênero epidítico, o qual Luciano performatiza. No Como se deve escrever a história, Luciano respeita o decoro de uma carta tratado-moral demonstrativo-deliberativa, de variante vituperadora. O como do título do texto indica modo, mas pode indicar a semelhança a ser observada na escrita da história, indicando argumentação também por analogia.

Em textos do século II d.C., como o de Luciano, estilo não significa o resultado subjetivado da iniciativa individual no discurso ou expressão de uma psicologia ou de uma biografia empírica, mas uma convenção de éthe ("caracteres"), páthe ("afetos"), tópoi e tipos correspondentes a um decoro ético-político-retórico. Lembre-se que o texto em questão deve ter sido proferido oralmente, em praça pública, tendo sido escrito, provavelmente, depois. Lembre-se também que, embora critique maus historiadores, o principal alvo do libelo é, indiretamente, o poder romano "contaminado" pela adulação, corrupção e presunção. Aspectos fundamentais para a definição do texto como sátira política.

O termo 'estilo' nomeia algo próprio da escrita. Paradoxalmente, nomeia a maneira individual de escrever e ao mesmo tempo conserva os três genera dicendi retóricos do costume (consuetudo), hoje chamados tradicionais. Isto é, humilde, médio, alto. Nomeia ainda categorias específicas da doutrina retórica: estilo inchado, árido, nervoso, frio, pomposo, abrupto etc. O que chamo de estilo médio, ou medíocre, humilde, é o médio 
horaciano próprio do deleite e do ensinamento. Funções básicas do texto de Luciano. A opção pela mediania, pela mediocridade, causa efeitos de liberdade temperada, cuja tópica principal da persona satírica é a temperança, virtude que se opõe ao vício da intemperança, com o qual Luciano retrata os historiadores criticados.

Os modelos de imitação/ emulação de Luciano podem ser identificados por meio da doutrina/ preceptiva epistolar encontrada na prática de letrados, como Demétrio e Filóstrato de Lemnos, de Caio Júlio Vítor, Cícero, Sêneca e de Gregório Nazianzeno etc. Lembro que a quinta sátira de Pérsio é composta como imitação de uma epístola de um jovem poeta a seu mestre. Possível modelo para Luciano da carta a Fílon para o decoro satírico. Entretanto, a relação de interlocução no segundo caso não refaz a hierarquia do primeiro, nem hierarquia nenhuma, pois se trata de imitação de conversa entre pares, amigos, entre iguais, como sabemos. $\mathrm{Ou}$, se quisermos, entre quem ensina a escrever história e um suposto aprendiz. Isso pode nos levar a pensar que Luciano emula o modelo, pois modifica as posições da interlocução. Lembre-se que emulação é uma imitação que "vence" o modelo. No caso, vale-se da mesma tópica, mas com variação da elocução. Por se colocar na posição de igual, de amigo, o "eu" do remetente não é descortês, podendo ser jocoso, como o é, uma vez que a posição não é de superioridade, mas nunca se coloca como orgulhoso, nem como presunçoso, pois o destinatário não lhe é inferior. ${ }^{2}$ Penso também na Epístola ad Pisones, a "Arte Poética" de Horácio, como possível modelo emulado por Luciano quanto ao decoro tratadístico, além, é claro, de Cícero, idealizador do perfeito orador.

Leio o Como se deve escrever a história como texto ficcional de gênero satírico, um misto, mescla de estilos médio e baixo, de matérias sérias e burlescas. Leio o texto como um monstro, portanto. Mistura de tratado ou ensaio ético-moral, carta/ epístola familiar/ negocial, cujas desproporções são convenientemente proporcionadas. Penso tanto nas desproporções do texto quanto nas que o texto refere sobre os tipos de historiadores e suas "notáveis" histórias. Ao propor encarar o texto de Luciano como sátira em prosa, observo a historicidade dos preceitos retóricos de sua invenção, disposição e elocução ficcionais em suas formas e funções epidíticas (ou demonstrativas) de variante vituperadora. Minha finalidade é a de desnaturalizar os critérios de expressividade de muitas das interpretações do polígrafo Luciano presentes na Universidade ou em círculos eruditos, onde ele principalmente é lido.

${ }^{2}$ Quintiliano, Inst. or. XI, I, 52. 
Ao especificar em termos retórico-poéticos o gênero sátira, o Como se deve escrever a história pode ser visto como formalidade prática que não se reduz aos propósitos psicológicos dos intérpretes atribuídos ao homem Luciano. Como gênero poético, a sátira Como se deve escrever a história é inventada como enunciação fictícia de um pronome pessoal, ego. É o "eu" não-substancial de um tipo que imita discursos epistolares, tratadísticos ou ensaísticos e panfletários, enquanto recompõe a dicção que especifica a adequação de seu estilo às tópicas da mistura para inventar e ornar a voz de seu éthos, caráter, movido por páthe, afetos.

No texto em questão, o estilo não é o homem Luciano, mas o destinatário, o ouvido do auctor. Objetivo refazer alguns dos artifícios retóricos mobilizados no ato da invenção poética do tipo, lendo o Como se deve escrever a história como um artefato em que o enunciador comunica ao destinatário res e uerba do costume cômico grego e satírico romano. A invenção do texto não é apenas mimética ou imitação verossímil de discursos sobre a bajulação, a estupidez, o descuido ou negligência intelectual, os defeitos físico-morais ou a inépcia etc. de pretensos historiadores relevantes no presente romano do polígrafo Luciano, mas também valorativos, constituindo no estilo os preceitos da recepção adequada da sua imitatio das paixões ridículas. Em outras palavras, o texto evidenciase para o destinatário também como preceito aplicado para performatizar tópicas satíricas, além, é claro, das tópicas da tratadística de gênero histórico. Luciano encena, no estilo, a posição adequada da qual o destinatário deve receber o texto para compreendê-lo também como comunicação da experiência coletiva dos preceitos técnicos aplicados à sua invenção e elocução. É claro que o conhecimento desses preceitos não é dado tão somente por meio do texto de Luciano. Depende também do conhecimento dos tratados de retórica, de filosofia, de ética coevos e anteriores ao polígrafo, além das convenções da comédia grega e da sátira romana.

Para demonstrar minha hipótese, sigo a divisão do texto, conforme propõe Homeyer, que estabelece dezenove parágrafos do Como se deve escrever a história como dedicados às negativas sobre a escrita da história, contra vinte e sete destinados aos preceitos. Os parágrafos 1-6 são introdutórios; o trecho 7-13 comenta a distinção entre história e encômio. O parágrafo 33 marca a passagem entre as duas partes maiores do texto, que totaliza 63 parágrafos. ${ }^{3}$ Essa divisão é importante não apenas como

\footnotetext{
${ }^{3}$ Cf. Homeyer, H. Lukian: wie man Geschichte schreiben soll, apud Brandão, op. cit., 2001, p. 279 .
} 
entendimento do modo de dispor as matérias no texto, mas para que se perceba que a comparação é um dos recursos mais trabalhados por Luciano, expediente central na construção do discurso, sistematizandose desde a parte introdutória do texto, passando pela parte das negativas, dos preceitos, até o final. Ocorre que a maior presença de comparações pode ser detectada na parte introdutória do texto e quando o remetente a Fílon se ocupa de distinguir história de encômio. Agora, se pensarmos na argumentação por analogia, por semelhança, fazendo-se metaforicamente, que é outro modo de comparar coisas (res), o expediente se dissemina pelo discurso todo. Em todo caso, penso com Pilar Gómez e Francesca Mestre que, no epidítico, as numerosas comparações compõem a suauitas retórica. ${ }^{4}$

Ao mesmo tempo em que analiso o uso de comparações e de outros tropos e figuras no texto de Luciano, verifico os lugares-comuns, as tópicas, principalmente lugares de pessoa (loci a persona) do vitupério prescritos por Quintiliano, ou seja, as prosopografias do retrato satírico, as descrições de pessoa, etopeias, principalmente, e antropografias (pintura do caráter/ pintura exterior). $\mathrm{O}$ misto deformado e incongruente resulta também da transferência metafórica ou comparativa de animado para animado; inanimado para inanimado; animado para inanimado e inanimado para animado. ${ }^{5}$ Ainda que monstruoso, bem mais saboroso do que meu texto é o texto de Luciano. Passo à leitura de excertos que comprovem o que venho afirmando aqui:

A fim de, como dizem, comparar isto àquilo, a doença de Abdera também agora sobreveio à maioria das pessoas cultas, fazendo-as não recitar tragédias (pois assim delirariam menos com jambos alheios, não se deixando contaminar por coisas medíocres), mas, a partir do momento em que a presente situação se instalou (...) não há ninguém que não escreva a história. Mais ainda, todos se tornam Tucídides, Heródotos e Xenofontes (...). [A guerra] fez brotar tantos historiadores com um só assalto. [\$2]

Veja-se o uso da comparação; enumeração de antonomásias metaforizadas nesse $\$ pertencente à introdução do texto. Detecto a referência aos jambos: alguns versos cômicos gregos de Arquíloco semelhantes à sátira romana. De saída, Luciano impõe o modo de ler o texto como sátira, não só pela anedota, mas por meio da mistura do

\footnotetext{
${ }^{4}$ Cf. Gómez y Mestre, op. cit., p. 354.

${ }^{5}$ Quintiliano, Inst. or. VIII, 6, 9.
} 
trágico alto com o baixo cômico. Impõe o procedimento comparativo, nuclear do texto. A anedota do $\$ anterior tem na doença ridícula uma tópica satírica. A referência à época de Lísimaco é aspecto temporal, tópica satírica também. No gênero se fala do passado (tempo de Lisímaco - 301 a.C.) para corrigir o presente (guerra de Marco Aurélio e Lúcio Vero contra partos - entre 162 e 165 d.C.). Isso fica claro no $\$ 2$, quando o narrador se refere ao presente da situação. A referência às pessoas cultas contaminadas por coisas medíocres na sátira também é tópica:

Vendo e ouvindo isso (...) ocorreu-me aquele caso do filósofo de Sinope (...). "Rolo também meu tonel”. [\$3]

Entendo com Canfora que a expressão inicial do $\ 3$ "introduz uma reação indignada", ${ }^{6}$ mas a interpreto como a posição da persona satírica, não como realidade ou não, nem face a fenômeno negativo, embora se trate de, com ironia, narrar episódio negativo. Narra-se episódio para estabelecer comparação com Diógenes. Trecho pertencente à introdução do texto. No trecho há, além da comparação, metáfora, em virtude da substituição de ações. Tonel está para história assim como rolar o objeto está para escrever.

A comparação com Diógenes, como defende Jacyntho Lins Brandão, é "logologia", emblema da diferença "no seio da instituição grega por excelência, a pólis, e da atividade grega por excelência, a filosofia". Nos dizeres de Brandão, "rolar o tonel"

Representa, de modo radical, o que vem a ser uma poética da diferença: para não ser o único desocupado com coisas úteis, o escritor empenhase seriamente numa atividade inútil. Em Como se deve escrever a história, rolar o tonel significa não escrever mais uma história da guerra, mas criticar as histórias que se escrevem, ou seja: não se trata de apenas repetir o que fazem os demais, mas de escrever com diferença de oitavas, ou, se quisermos, praticar uma escrita em segundo grau, o que é próprio do discurso crítico. ${ }^{7}$

A oposição estabelecida se dá por meio das noções de utilidade/ inutilidade. A primeira se refere ao critério historiográfico, enquanto que a segunda por meio de uma tópica cínica:

\footnotetext{
${ }^{6}$ Cf. Canfora, op. cit., p. 42-43.

${ }^{7}$ Cf. Brandão, op. cit., 2001, p. 138-139.
} 
O que proporei aos historiadores é uma pequena exortação e alguns poucos conselhos, a fim de 'participar da construção de sua obra, se não da inscrição, pelo menos tocando a argamassa com a ponta do dedo. [ $\llbracket 4]$

No início do $\ 4$, trecho que não transcrevi, o narrador diz não ser atrevido e que seu tonel é tonelzinho, por isso tomará parte na guerra com segurança, elevando-se no que faz bem. Comentários que podem ser lidos como o posicionamento da pessoa satírica, humilde, prudente, ajuizada, que contrasta com os imprudentes historiadores, objetos da sátira. Atente-se para a metáfora continuada (alegoria) em comparação com arquitetura, edificação, escultura, na relação de semelhança entre arte histórica e arte estatuária, com as matérias manejadas pelo historiador e pelo artífice. Passagem que pertence também à introdução do texto. Tocar com a ponta do dedo pode ser lido como "de leve", ligeiro, demonstrando humildade, posição da persona satírica, mas também do tratadista de arte histórica desempenhado em estilo médio:

A maioria [dos historiadores], descuidando-se de narrar o que aconteceu, demora-se em elogios aos comandantes e generais, elevando os seus às alturas e rebaixando os inimigos além da medida, por ignorar que não é estreito o istmo que delimita e separa a história do encômio, mas há uma elevada muralha entre eles e, como na música, uma dupla escala entre uma e outro”. [\$7]

Veja-se, acima, a comparação atrelada à metáfora continuada, a alegoria. Trecho pertencente à parte em que se diferencia a história do encômio na figura dos historiadores desmedidos:

Um grande defeito (...) é se alguém não sabe separar o que é da história daquilo que pertence à poesia, mas introduz na história os adornos da outra (...) como se vestisse um desses atletas fortes e completamente resistentes com uma túnica de púrpura e outros enfeites de cortesãs e lhe esfregasse no rosto ruge e pó-de-arroz. Por Héracles! como você o tornaria ridículo, envergonhando-o com essa aparência. [\$8]

Entendo, aqui, a comparação atrelada à metáfora continuada, a alegoria, mais uma vez. Outro exemplo retirado da parte do texto em que se diferencia a história do encômio. Veja-se o lugar de pessoa de que Quintiliano prescreve para o retrato epidítico, no caso vituperador, sexo (feminino no masculino - misoginia, não "machismo", virilidade/ feminilidade etc.), cuja transferência metafórica ocorre do inanimado para o inanimado (roupas, trajes). Outro lugar de pessoa aqui pode ser entendido: aparência, o que aparenta ser, na transferência metafórica do 
inanimado para o animado. Decoro no traje humano, em um dos tipos retratados:

Quanto ao prazeroso, o melhor é se acompanha aquele, como a beleza ao atleta (...). Assim, a história, se além do mais se ocupa de passagem com o prazeroso, pode atrair muitos amantes, mas, até que tenha atingido sua finalidade própria - digo: a publicação da verdade - se preocupará pouco com a beleza. [\$9].

Atente-se para a comparação da história com o tipo do atleta na relação prazer/ beleza, cujo trecho localiza-se na parte em que se diferenciam história e encômio:

Se você não pensa na chusma e na massa do povo, mas, por Zeus! naqueles que o ouvirão como juízes e acusadores, aos quais nada passaria despercebido, por lançarem um olhar mais agudo que o de Argos por todas as partes do corpo e avaliarem cada coisa dita como se fossem cambistas, de modo a rejeitar imediatamente o que for falso, recebendo as moedas verdadeiras, legal e perfeitamente cunhadas (...). Mas se, fazendo pouco daqueles, você adoçar a história, além da medida, com mitos, elogios e outros agrados, logo a fará semelhante a Héracles na Lídia. [ \10]

Acima, há várias comparações. Lembre-se que a tópica das moedas falsas é lugar-comum cínico, conforme explica Olimar Flores Jr. ${ }^{8} \mathrm{O}$ excerto pertence à parte em que há distinção entre os gêneros histórico e encomiástico. Detecto a tópica da malícia, da falsidade, subcategorias da intemperança, previstas na Ética a Nicômaco. O principal sentido dessa tópica é denunciar e rebaixar quem tira proveito de outrem. Veja-se também que a exclamação funciona como interjeição, muitas vezes repetida pelo narrador, do discurso patético, que afeta o destinatário. "Por Zeus!" equivale a "pelo amor de Deus!", de muito uso vulgar, ou "valha-me Deus!". Creio que, na sátira antiga, a fórmula é elegante, urbana (urbanitas), uma das qualidades do estilo:

(...) Quando se deparam com feitos múltiplos e grandes, assemelhamse [os historiadores ignorantes] a um serviçal há pouco enriquecido, por ter herdado a fortuna do patrão: ele não sabe nem como deve portar a vestimenta, nem como comer com bons modos, mas, com todo ânimo, tendo com frequência diante de si aves, porcos e lebres, empanturra-se de purê de legumes e carne defumada até arrebentar de comer. [\$20]

\footnotetext{
${ }^{8}$ Cf. Flores Jr., op. cit. [apud Brandão, op. cit., 2009, p. 123 (n. 23)].
} 
O extrato acima se ocupa em condenar descrições históricas inúteis e sem vigor, cuja comparação pertence às negativas. É possível ler o lugar de pessoa condição. No final desse $\ 20$, a persona satírica se coloca na posição de sensato. Veja a frase irônica: "Não sei como alguém sensato pode aguentar uma coisa dessas!”. A exclamação afeta o destinatário, que é induzido a pensar no historiador retratado como insensato, ridículo:

Como esse negócio se parece com um ator trágico que calçou um pé num alto coturno, enfiando o outro numa sandália! [\$22]

Acima, vê-se a comparação entre historiador decoroso e indecoroso no uso do gênero histórico. Trecho alocado na parte das negativas:

Mas o corpo da história que acrescentam [os historiadores] é minúsculo e vulgar, o que o assemelha a um menininho (...). Você poderia sem dúvida ver muitos historiadores desse tipo, os quais põem a cabeça do ‘Colosso' de Rodes num corpo de “anão”. [\$23]

Ao falar sobre proêmios do discurso histórico, o remetente compara o decoro do discurso com o decoro (ou falta dele) das artes mecânicas, particularmente à escultura. Trecho disposto na parte das negativas. Vejase a desproporção proporcionada, gigante/ anão, sendo que as duas figuras são tópicas da sátira, uma porque excessiva, outra porque faltante. Tanto anão quanto gigante são ridículos, funcionariam como hipérboles, uma para menos (anão), outra para mais (gigante). O lugar de pessoa evidente é idade performatizado na figura do "menininho":

Que o historiador se pareça com Zeus de Homero (...) que se pesem os acontecimentos como numa balança. [\$49].

Vejam-se as comparações localizadas na parte dos preceitos. Nesse $§ 49$, o narrador ainda vai dizer que se evitem o excesso, a grosseria ou a puerilidade, tópicas satíricas, sendo que a da puerilidade é lugar de pessoa idade:

Que seu pensamento se torne semelhante a um espelho impoluto, brilhante, preciso quanto a seu centro (...) quem escreve a história deve assemelhar-se a um Fídias, um Praxíteles, um Alcâmenes ou outro artista desse tipo (...). Eles apenas moldavam, cortavam o marfim, poliam, colavam, ajustavam e ornavam-no com ouro - sendo essa sua arte: tratar a matéria como se deve. [ $₫ 50]$ 
Veja-se a comparação entre historiador e escultores, em comparação acumulada, saturada, com espelho. Atente-se para a semelhança, não para a igualdade. Trata-se da questão do decoro também. O trecho faz parte dos preceitos. A transferência metafórica se dá entre animado/ animado; animado/ inanimado em saturação. Jacyntho Lins Brandão identifica ${ }^{9}$ a relação discursivo-pictórica quando do uso de comparações das chamadas metáforas "plásticas" no Como se deve escrever a história, por meio do conceito ut pictura poesis, das auctoritates Simônides de Cós, Plutarco e Horácio. A sentença foi utilizada por Plutarco para "elogiar a capacidade de os poetas e pintores imitarem com vivacidade afetos e personagens", como localiza Adma Muhana. ${ }^{10}$

Concordo com Brandão que o conceito ut pictura poesis, embora não formulado de modo literal, esteja presente na argumentação do discurso luciânico. Não obstante, proponho que a tópica antiga da emulação entre pintura e poesia seja formulada, no texto de Luciano, em termos de ut pictura historia, pensando-a por homologia ao ut pictura poesis. Penso que há emulação da tópica, pois Luciano propõe a história como pintura, como escultura, em uma espécie de ut pictura historia. Entre os vários exemplos de usos antigos da tópica, lembro de Tácito, das Histórias, que diz "pintar" a aparência miserável de Roma: "Pintase el miserable aspecto de Roma".

Talvez Luciano não faça um "bom" tratado, nem um manual metodológico ou um panfleto interessantíssimo, talvez sua qualidade seja inferior a outros textos semelhantes, seja "pobre", cheio de "clichês" escolares, mas Luciano faz "boa" sátira no Como se deve escrever a história, na medida em que desconstrói gêneros, como o faz no Das narrativas verdadeiras, que de verdadeiras não têm nada, ou no Banquete, que é antibanquete. Talvez o escritor não seja "original", no sentido do termo hoje, mas êmulo de auctoritates, cuja originalidade é licença poética, variação da elocução. Luciano, no Como se deve escrever a história, ocupa-se de matérias altas em tom médio e baixo, de matérias baixas em tom baixo e de matérias médias em tons médio/ baixo. A mediania é uma das componentes estilísticas demandadas, não exclusiva.

\footnotetext{
${ }^{9}$ Cf. Brandão, op. cit., 2001, p. 77; p. 89-90.

${ }^{10}$ Cf. Muhana, op. cit., p. 12.

${ }^{11}$ Cf. Tácito, op. cit., p. 614 (L, IV, “argumento”).
} 


\section{Referências}

BRANDÃO, J. L. A Poética do Hipocentauro: literatura, sociedade e discurso ficcional em Luciano de Samósata. Belo Horizonte: UFMG, 2001.

BRANDÃO, J. L. Como se deve escrever a história. Edição bilíngue. Trad. e ensaio de Jacyntho Lins Brandão. Belo Horizonte: Tessitura, 2009.

CANFORA, L. Teorie e tecnica della storiografia classica: Luciano, Plutarco, Dionigi, anonimo su Tucidide. Roma: Laterza, 1974.

FLORES Jr., O. Canes sine coda. Dissertação de mestrado inédita em filosofia. Belo Horizonte: Faculdade de Letras da UFMG, 2006.

GÓMEZ, P.; MESTRE, F. Luciano y la tradición de la mosca. In: CALDERÓN, E.; MORALES, A.; VALVERDE, M. (org.). Koinòs Lógos: homenaje al profesor José García López. Murcia: Universidad de Murcia, Servicio de Publicaciones, 2006.

MUHANA, A. Poesia e pintura ou pintura e poesia: tratado seiscentista de Pires de Almeida. São Paulo: FAPESP/EDUSP, 2002.

QUINTILIANO. Instituição Oratória. Traduzida com notas críticas, históricas e retóricas de Jeronymo Soares Barboza. Tomo I. Coimbra: Imprensa Real da Universidade, 1788; Tomo II. Paris: Livraria Portuguesa de J. P. Aillaud, 1836 (reedição da edição de 1788).

TÁCITO. Histórias. Trad. Carlos Coloma. Buenos Aires: El Ateneo, 1952. 